INDONESIA ACCOUNTING JOURNAL

VOLUME 2, NUMBER 2, YEAR 2020

${ }^{1}$ Corresponding author

Jurusan Akuntansi

Fakultas Ekonomi dan Bisnis

Universitas Sam Ratulangi

Jl. Kampus UNSRAT

Manado, Indonesia, 95115

E-mail: herlentumbelaka@yahoo.com

${ }^{2,3}$ Jurusan Akuntansi

Fakultas Ekonomi dan Bisnis

Universitas Sam Ratulangi

Jl. Kampus UNSRAT

Manado, Indonesia, 95115

Article info:

Received 24 January 2020

Accepted 25 January 2020

Available online 27 January 2020

Keywords: analysis; village fund management

JEL Classification: M41, $\mathrm{H}_{53}$

DOI: http://doi.org/10.32400/iaj.27703

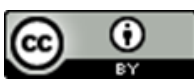

\section{Analisis pengelolaan dana desa studi kasus di Kecamatan Tatapaan Kabupaten Minahasa Selatan○}

\author{
Herlen Indrakartika Angela Tumbelaka ${ }^{1}$ \\ Inggriani Elim ${ }^{2}$ \\ Meily Kalalo
}

\begin{abstract}
Village funds are funds sourced from the State Revenue and Expenditure Budget allocated for villages transferred through the Regency/City Regional Revenue and Expenditure Budget and is used finance governance, devolpment, community devolpment ang community empowerment. According to permendagri No.113, 2014 explains that village financial management is the whole activity which include Planning, Implementation, Administration, Reporting and Accountability. This study aims to determine how the management of village funds in the district of Tatapaan in the village of sulu, paslaten village, Paslaten Satu village, Popareng village, Pungkol Village, Sondaken village, Arakan village and Rap-Rap village whether in accordance with permendagri No. 113,2014 or not. The result of the study showed that the Planning, Implementation and Administration stages were in accordance with Permendagri No. 113,2014 but for Reporting and Accountability there are obstacles so it not in accordance with Permendagri No. 113,2014.
\end{abstract}

\section{Pendahuluan}

Undang-Undang No 6 Tahun 2014 tentang Desa pasal 1 menjelaskan bahwa Desa merupakan kesatuan masyarakat hukum yang memiliki batas wilayah yang berwenang untuk mengatur dan mengurus urusan pemerintahan, kepentingan masyarakat setempat berdasarkan prakarsa masyarakat, hak asal usul dan/atau hak tradisional yang diakui dan dihormati dalam sistem pemerintahan Negara Kesatuan Republik Indonesia. Desa dalam pengertian umum adalah sebagai suatu gejala yang bersifat universal, yang terikat pada lokalitas tertentu baik sebagai tempat tinggal (secara menetap) maupun bagi pemenuhan kebutuhannya.

Menurut Peraturan Menteri Dalam Negeri No 113 Tahun 2014 Pemerintahan Desa adalah penyelenggaraan urusan pemerintahan dan kepentingan masyarakat setempat dalam sistem pemerintahan Negara Kesatuan Republik Indonesia. Pemerintah
Desa adalah Kepala Desa atau yang disebut dengan nama lain dibantu Perangkat Desa sebagai unsur penyelenggara pemerintahan desa. Kewenangan Desa diatur pada pasal 18 Undang-Undang No 6 Tahun 2014, Kewenangan Desa meliputi kewenangan di bidang penyelenggaran Pemerintahan Desa, pelaksanaan Pembangunan Desa, pembinaan Kemasyarakatan Desa dan pemberdayaan masyarakat desa berdasarkan prakarsa masyarakat, hak asal usul dan adat istiadat desa.

Hal ini menunjukkan bahwa desa merupakan suatu langkah awal kemandirian desa dalam penyelenggaran pemerintah maupun dalam pengelolaan dana desa. Dalam pelaksanaannya desa akan bersentuhan langsung dengan masyarakat dalam peranan desa memberikan pelayanan kepada publik khususnya kepada masyarakat, maka diharapkan dalam penyelenggaraan pemerintah dan pengelolaan dana desa dibutuhkan aparat 
pemerintah yang handal serta sarana dan prasarana yang memadai agar pelaksanaannya lebih terarah dan sesuai dengan tata kelola yang baik. Dana desa yang mulai dijalankan pada tahun 2015 memberikan kepastian hukum terhadap pertimbangan keuangan desa dan kabupaten/kota, desa memiliki jatah yang digunakan untuk mengelola dana desa. pemerintah, pelaksanaan pembangunan, pembinaan kemasyarakatan, serta pemberdayaan masyarakat. Dana desa yang diberikan kepada desa akan dikelola oleh pemerintah desa, agar tujuan adanya dana desa dapat tercapai.

\section{Tinjauan pustaka}

Akuntansi. Suwardjono (2017:5) mengemukakan bahwa akuntansi merupakan seni pencatatan, penggolongan dan peringkasan transaksi dan melaporkan kejadian aktivitas serta dalam konstruksi satuan uang untuk menginterpretasikan impak proses yang terjadi. Warren et al. (2015:2) mendefinisikan akuntansi sebagai seni mencatat, menggolongkan, dan meringkas transaksi keuangan dengan cara tertentu dan sains yang menjelaskan akuntansi dari fenomena objektif dengan apa adanya serta bebas nilai. Thomas (2013:1) menyatakan akuntansi merupakan seni mengumpul, mengidentifikasi, mengklasifikasi, mencatat transaksi keuangan, untuk menghasilkan informasi laporan keuangan yang bisa digunakan oleh pihak yang berkepentingan.

Akuntansi sektor publik. Menurut Sujarweni (2015:1), akuntansi sektor publik dapat didefinisikan sebagai aktivitas jasa yang terdiri dari mencatat, mengklasifikasikan dan melaporkan kejadian atau transaksi ekonomi yang akhirnya akan menghasilkan suatu informasi keuangan yang akan dibutuhkan oleh pihak-pihak tertentu untuk pengambilan keputusan yang diterapkan pada pengelolaan dana publik di lembaga-lembaga tinggi Negara dan departemen-departemen dibawahnya. Menurut Rondonuwu et al. (2015:23), akuntansi sektor publik di Indonesia pada berbagai entitas yakni sebagai berikut: akuntansi pusat, akuntansi pemerintahan, akuntansi desa, akuntansi tempat ibadah : masjid, gereja, pura, wihara, akuntansi lsm, akuntansi yayasan, akuntansi pendidikan: sekolah, perguruan tinggi, akuntansi kesehatan: puskesmas, rumah sakit. Menurut Bastian (2012:6), akuntansi sektor publik dapat didefinisikan sebagai mekanisme teknik dan alat analisis akuntansi yang diterapkan pada pengelolaan dana masyarakat di lembaga-lembaga tinggi negara dan departemen-departemen dibawahnya, pemerintah daerah, BUMN, BUMD, LSM dan Yayasan Sosial, maupun pada proyek-proyek kerjasama sektor publik dan swasta.

Tujuan akuntansi sektor publik. Menurut Halim (2014: 4) tujuan akuntansi sektor public adalah: (1) akuntabilitas yang ada di dalam pemerintahan, keuangan Negara yang dijalankan harus dapat dipertanggungjawabkan sebagaimana mestinya sesuai dengan peraturan dan amanat konstitusi; dan (2) manajerial akuntansi pemerintahan dapat memungkinkan pemerintah untuk menjalankan suatu perencanaan yang berkaitan dengan penyusunan APBN dan strategi pembangunan-pembangunan lainnya, agar dapat melakukan pelaksanaan kegiatan pembangunan dan pengendalian atas kegiatan yang dilakukan tersebut dalam rangka untuk mencapai ketaatan kepada peraturan perundang-undangan yang efisiensi, efektivitas, dan ekonomis.

Pengukuran kinerja sektor publik. Mahmudi (2015:6) menjelaskan bahwa pengukuran kinerja merupakan suatu proses penilaian kemajuan pekerjaan terhadap pencapaian tujuan dan sasaran yang telah ditentukan, termasuk informasi atas efisiensi penggunaan sumber daya dalam menghasilkan barang dan jasa, kualitas barang dan jasa, perbandingan hasil kegiatan dengan target, dan efektivitas tindakan dalam mencapai tujuan.

Akuntansi pemerintahan. Menurut Sujarweni (2015:18), akuntansi pemerintahan adalah akuntansi yang bersangkutan dengan bidang keuangan negara, dari anggaran sampai dengan pelaksanaan dan 
pelaporannnya, termasuk segala pengaruh yang di timbulkannya. Menurut Halim (2012:3), akuntansi pemerintahan adalah suatu proses pengidentifikasian, pengukuran, pencatatan dan pelaporan transaksi ekonomi (keuangan) dari suatu organisasi atau etnis publik seperti pemerintah, LSM dan lain-lain yang dijadikan sebagai informasi dalam rangka mengambil keputusan ekonomi oleh pihak-pihak yang memerlukan. Pada hakekatnya akuntansi pemerintahan adalah aplikasi akuntansi di bidang keuangan negara (public finance), khususnya pada tahapan pelaksanaan anggaran (budget execution), termasuk yang ditimbulkannya, baik yang bersifat seketika maupun yang lebih permanen pada semua tingkatan dan unit pemerintahan, tuntutan transparansi dan akuntabilitas publik atas penggunanaan akuntansi dalam mencatan dan melaporkan kinerja pemerintahan (Dedi, 2012:1).

Akuntansi desa. Menurut Peraturan Menteri Dalam Negeri No 113 Tahun 2014 Akuntansi Desa adalah pencatatan dari proses transaksi yang terjadi di desa, dibuktikan dengan nota-nota kemudian dilakukan pencatatan dan pelaporan keuangan sehingga akan menghasilkan informasi dalam bentuk laporan keuangan yang digunakan pihak-pihak yang berhubungan dengan desa. Pihak-pihak yang menggunakan informasi keuangan desa di antaranya adalah: (1) masyarakat desa; (2) perangkat desa; (3) pemerintah daerah; dan (4) pemerintah pusat.

Desa. Menurut Peraturan Menteri Dalam Negeri No 113 Tahun 2014 Desa adalah desa dan desa adat atau yang disebut dengan nama lain, selanjutnya disebut Desa, adalah kesatuan masyarakat hukum yang memiliki batas wilayah yang berwenang untuk mengatur dan mengurus urusan pemerintahan, kepentingan masyarakat setempat berdasarkan prakarsa masyarakat, hak asal usul, dan/atau hak tradisional yang diakui dan dihormati dalam sistem pemerintahan Negara Kesatuan Republik Indonesia. Pemerintah Desa terdiri dari Kepala Desa dan Perangkat Desa, yang meliputi Sekertaris Desa dan Perangkat Desa lainnya.
Dana desa. Menurut Peraturan Menteri Dalam Negeri No 113 Tahun 2014 tentang pengelolaan keuangan desa, bahwa dana desa merupkan dana yang bersumber dari Anggaran Pendapatan dan Belanja Negara (APBN) yang diperuntukan bagi desa yang ditransfer melalui Anggaran Pendapatan dan Belanja Daerah kabupaten/kota dan digunakan untuk membiayai penyelenggaran pemerintah, pelaksanaan pembangunan, pembinaan kemasyarakatan, dan pemberdayaan masyrakat.

\section{Peraturan Menteri Dalam Negeri No}

113 Tahun 2014. Menurut Peraturan Menteri Dalam Negeri No 113 Tahun 2014 Pengelolaan Keuangan Desa adalah keseluruhan kegiatan yang meliputi perencanaan, pelaksanaan, penatausahaan, pengelolaan dan pertanggungjawaban keuangan desa.

Penelitian terdahulu. Penelitian yang telah dilakukan oleh Shuha et al. (2018) menunjukan bahwa tujuan penelitian untuk mengetahui bagaimana pengelolaan dana desa di desa-desa selingkungan Kecamatan Lubuk Alung Kabupaten Padang Pariaman serta faktor-faktor penghambat pengelolaan dana desa dengan metode penelitian kualitatif dan hasil penelitian menunjukan bahwa perencanaan telah sesuai dengan Permendagri No. 113 Tahun 2014 tentang pengelolaan keuangan desa sedangkan pelaksanaan, penatausahaan, pelaporan dan pertanggungjawaban tidak sesuai dengan Permendagri No. 113 Tahun 2014. Faktor penghambat pengelolaan dana desa di Kecamatan Lubung Agung yaitu, sumber daya manusia, keterlambatan pelaporan, perubahan APBDesa, internet dan pemahaman masyarakat. Bawon et al. (2018) menunjukan bahwa proses perencanaan dan penganggaran dana Desa Passi 2 sudah sesuai dengan permendagri 113 tahun 2014 dan permendes nomor 2 tahun 2015 serta Peraturan Desa yang sudah ditetapkan bersama. Proses pelaksanaan pengelolaan dana Desa Passi 2 sudah sesuai dengan permendagri 113 tahun 2014. Mekanisme penatausahaan Keuangan Desa Passi 2 sudah sesuai dengan peraturan tentang pengelolaan alokasi dana desa. Laporan 
pengelolaan keuangan dana Desa Passi 2 sudah sesuai dengan permendagri 113 tahun 2014. Laporan pertanggungjawaban keuangan desa pada Desa Passi 2 kecamatan passi barat belum sesuai dimana masih bayak masalah dalam pembuatan laporan Pertanggungjawaban dana desa yang sering terlambat dikarenakan hambatan-hambatan seperti Kualitas Sumber Daya Manusia, Tim pendamping kecamatan, dan tim pendamping desa yang ada di Desa Passi 2 Kecamatan Passi Barat Kabupaten Bolaang Mongondow.

\section{Metode penelitian}

Penelitian ini menggunakan jenis penelitian kualitatif dengan metode deskriptif. Metode deskriptif dalam penelitian ini yaitu dimana peneliti mendatangi langsung tempat objek penelitian yaitu Kecamatan khususnya 4 (empat) desa yaitu Desa Sulu, Desa Paslaten, Desa Pungkol, dan Desa Rap-Rap dengan tujuan untuk memperoleh data-data dan informasi yang berhubungan langsung dengan penelitian mengenai pengelolaan keuangan desa dalam hal ini pengelolaan dana desa. Penelitian ini dilakukan di Desa Sulu, Desa Paslaten, Desa Pungkol, dan Desa Rap-Rap. Waktu penelitian dilakukan bulan September sampai dengan selesai. Jenis Data yang digunakan adalah data kualitatif berupa hasil wawancara dengan pemerintah desa (Plt.Hukum Tua dan Sekertaris Desa). Sumber data dalam penelitian ini menggunakan data primer berupa data yang diperoleh dari hasil wawancara dengan narasumber. Sedangkan Metode Pengumpulan Data yang digunakan berupa wawancara dan dokumentasi.

Metode analisis data yang digunakan dalam penelitian ini adalah metode deskriptif, yaitu membahas masalah dengan mengumpulkan, menguraikan dan menjelaskan suatu keadaan sehinggah dapat ditarik kesimpulan. Proses analisis yang dilakukan dalam penelitian ini yaitu: (1) mengajukan permohonan penelitian pada Kecamatan Tatapaan; (2) mengumpulkan data-data yang diperlukan dalam penelitian ini dengan cara melakukan wawancara dan mendokumentasi data-data yang diperlukan dalam penelitian ini; (3) menganalisa dan mengolah data yang ada tentang pengelolaan dana desa di Kecamatan Tatapaan kususnya di Desa Sulu, Desa Paslaten, Desa Pungkol, dan Desa Rap-Rap apakah sudah sesuai dengan permendagri No. 113 Tahun 2014 atau belum; (4) menarik kesimpulan dari pembahasan dan perbandingan yang telah dilakukan; dan (5) memberikan saran jika ditemukan sesuatu yang tidak sesuai atau yang dapat diperbaiki oleh objek penelitian.

\section{Hasil penelitian dan pembahasan \\ Hasil penelitian}

Kecamatan Tatapaan terdiri dari 11 (sebelas) desa yaitu Desa Sulu, Desa Paslaten, Desa Paslaten Satu, Desa Wawona, Desa Bajo, Desa Popareng, Desa Wawontulap, Desa Pungkol, Desa Sondaken, Desa Arakan dan Desa Rap-Rap, dimana untuk tingkat kecamatan dipimpin oleh seorang camat sedangkan untuk tingkat desa dipimpin oleh seorang kepala desa (hukum tua) yang dipilih langsung oleh rakyat. Seluruh desa di Kecamatan Tatapaan berstatus desa, dimana untuk masing-masing desa dibagi menjadi beberapa Satuan Lingkungan Setempat (SLS) yang diberi nama jaga dan masing-masing jaga dipimpin oleh seorang kepala jaga.

\section{Desa Sulu}

a. Perencanaan. Hasil penelitian dan wawancara yang dilakukan bersama dengan informan yaitu Bpk. Donald Lamia dimana dalam tahap perencanaan berawal dari penggalian gagasan mulai dari jaga-jaga atau musyawarah antar jaga selanjutnya musyawarah pembangunan desa untuk menggali gagasan untuk mengetahui apa-apa yang akan dibangun ditahun selanjutnya. Setelah itu kita membuat RKPDes setelah itu membuat APBDes. (Tahap Perencanaan sudah sesuai dengan Permendagri No. 113 Tahun 2014).

b. Pelaksanaan. Setelah adanya pencairan dana maka akan dilaksanakan pembangunan. Setiap transaksi yang muncul baik itu penerimaan atau 
pengeluaran kas melalui rekening kas desa. (Tahap Pelaksanaan sudah sesuai dengan Permendagri No. 113 Tahun 2014).

c. Tahap Penatausabaan. Dalam penatausahaan pastinya setiap desa memiliki bendahara desa yang berfungsi untuk melakukan pengadministrasian atau penatausahaan. (Tahap Penatausahaan sudah sesuai dengan Permendagri No. 113 Tahun 2014).

d. Pelaporan. Untuk pelaporan dana desa atau keuangan desa yang ada di Desa Sulu terjadi keterlambatan apalagi tahun 2017 masih dilakukan secara manual namun untuk tahun 2018 sudah menggunakaan sistem yang disebut siskeudes, terjadi hambatan juga karena SDM dalam hal ini Sekertaris Desa yang sampai saat ini sudah 3 kali pergantian sekdes. (Tahap Pelaporan belum sesuai dengan Permendagri No. 113 Tahun 2014).

e. Tahap pertanggungjawaban. Untuk Desa Sulu tentunya harus dan pasti melakukan pertanggungjawaban dan dilakukan secara transparan lewat dibuatnya baliho laporan realisasi pelaksanaan APBDesa yang dipajang di depan BPU. (Tahap Pertanggungjawaban sudah sesuai dengan Permendagri No. 113 Tahun 2014).

\section{Desa Paslaten}

a. Perencanaan. Dari Hasil penelitian dan wawancara yang dilakukan bersama dengan informan yaitu Bpk. Moudy Moniung, SE, M.Pd selaku Sekertaris Desa Paslaten dimana awalnya penyusunan Rancangan Peraturan Desa tentang APBDes berdasarkan RKPDes dimulainya dari penggalian gagasan mulai dari jaga-jaga dari jaga 1 sampai jaga 5 disitu kita ambil gagasan/ide yang dianggap paling tepat untuk dibawah dalam musyawarah desa. APBDes tahun 2018 dibuat atau disusun tahun 2017 itu kami sebagai pemerintah desa bersama Tim penyusun yang ada. Setelah APBDes disepakati oleh Pemerintah Kabupaten maka kita tinggal menunggu pencairan dana desa. (Tahap
Perencanaan sudah sesuai dengan Permendagri No. 113 Tahun 2014).

b. Tahap Pelaksanaan. Setelah adanya pencairan dana desa maka kita akan segera melaksanakan proses pembangunan dalam hal ini apa-apa saja yang telah diprogramkan dan diprioritaskan. (Tahap Pelaksanaan sudah sesuai dengan Permendagri No. 113 Tahun 2014).

c. Tahap Penatausahaan. Yang bertugas menatausahakan adalah bendahara desa, bendahara desa dalam hal ini mencatat setiap transaksi yang terjadi kedalam buku catatan yang ada. (Tahap Penatausahaan sudah sesuai dengan Permendagri No. 113 Tahun 2014).

d. Tahap Pelaporan. Dalam proses pelaporan dana desa di Desa Paslaten terjadi hambatan karena untuk tahun 2017 masih manual dan tahun 2018 sudah dipermudah dengan adanya sistem yang disebut siskeudes tapi ada juga hambatan lain misalnya hibah lahan dari pemilik lahan jadi ketika sudah akan mulai dalam proses pengerjaan (proyek) terjadi keterlambatan pekerjaan karena hibah lahan oleh keluarga sehingga dalam pelaporanpun ikut terhambat. (Tahap Pelaporan belum sesuai dengan Permendagri No. 113 Tahun 2014).

e. Tahap Pertanggungjawaban. Pada tahap ini semua harus mempertanggungjawabankan laporan realisasi pelaksanaan kepada pimpinan yang ada. (Tahap Pertanggungjawaban sudah sesuai dengan Permendagri No. 113 Tahun 2014).

\section{Desa Pungkol}

a. Perencanaan. Dari hasil penelitian dan wawancara yang dilakukan bersama dengan informan Bpk. Leond Walukow selaku Sekertaris Desa Pungkol dimana pada tahap perencanaan waktu hukum tua terpilih menjadi hukum tua definitif yang dilakukan pertama yaitu membuat RPJMDes semua itu sudah ada mulai dari penggalian gagasan dari masyarakat mulai dari jaga untuk 6 tahun kedepan sesuai dengan masa jabatan hukum tua dan sesuai dengan visi misi, selanjutnya 
setiap tahun dasar RPJMDes ini dibuat RKPDes untuk dasar dalam pembuatan APBDes. Setiap tahun ada tim yang dipilih langsung oleh hukum tua untuk menjadi tim perumus RKP untuk tahun selanjutnya dan tim pencermatan ulang RPJMDes karena ada rencana-rencana yang mungkin disesuaikan dengan permendes untuk prioritas dana desa itu ada tim yang akan mengerjakannnya. Untuk adanya pencairan dana maka harus adanya kelengkapan berkas untuk pencairan biasanya yang diminta adalah APBDes tahun berjalan setelah itu baru dilakukan proses pencairan dana, pencairan itu sudah ada rincian penggunaan anggaran. (Tahap Perencanaan sudah sesuai dengan Permendagri No. 113 Tahun 2014).

b. Pelaksanaan. Setelah adanya pencairan dana akan dilakukan pelaksanaan pembangunan dan setiap penerimaan dan pengeluaran kas didesa kami itu melalui reking kas desa, jadi tidak melalui reking milik orang lain. (Tahap Pelaksanaan sudah sesuai dengan Permendagri No. 113 Tahun 2014).

c. Penatausabaan. Penatausahaan adalah tugas dari Bendahara Desa karena bendahara desa yang mempertanggungjawabkan uang melalui laporan pertanggungjawban (Tahap Penatausahaan sudah sesuai dengan Permendagri No. 113 Tahun 2014).

d. Tahap Pelaporan. Dalam tahap ini yang menjadi kendala di desa kami karena pada tahun 2017 pencairan agak terlambat sehingga pelaporanpun agak terlambat, untuk tahun 2018 tidak ada. (Tahap Pelaporan belum sesuai dengan Permendagri No. 113 Tahun 2014).

e. Tahap Pertanggungjawaban. Pastinya semua desa yang ada di Kecamatan Tatapaan setelah adanya pelaksanaan akan membuat laporan pertanggungjawaban. (Tahap Pertanggungjawaban sudah sesuai dengan Permendagri No. 113 Tahun 2014).

\section{Desa Rap-Rap}

a. Perencanaan. Dari hasil penelitian dan wawancara yang dilakukan bersama dengan informan Bpk. Yusak Kasenda selaku Sekertaris Desa Rap-Rap dimana pada tahap Perencanaan kami disini menjalankan sesuai dengan aturan dimana dalam tahap perencanaan semua harus dibahas di musyawarah desa jadi semua usulan harus termuat di RKPDes selanjutnya oleh Tim 11 melakukan perumusan yang tertuang di APBDes. Musyawarah RKPDes melibatkan semua unsur BPD, LPM, dan Perangkat Desa. (Tahap Perencanaan sudah sesuai dengan Permendagri No. 113 Tahun 2014).

b. Pelaksanaan. Untuk proses pelaksanaan APBDes didalam musrembang desa akan ada prioritas usulan yang akan didanai oleh dana desa ata sebelumnya sudah ada pemilihan usulan-usulan kegiatan yang akan didanai oleh SKPD, APBD 1, APBD2 ataupun APBD dan didesa kami semua penerimaan ataupun pengeluaran kas/uang melalui rekening kas desa. (Tahap Pelaksanaan sudah sesuai dengan Permendagri No. 113 Tahun 2014).

c. Tahap Penatausabaan. Yang bertugas menatausahakan adalah Bendahara Desa dan Bendahara Desa juga bertugas mempertanggungjawabkan laporan pelaksanaan melalui laporan pertanggungjawaban. (Tahap Penatausahaan sudah sesuai dengan Permendagri No. 113 Tahun 2014).

d. Tahap Pelaporan. Dalam pelaporan di desa kami kadang terjadi keterlambatan karena kadang pekerjaan sering berbenturan dengan kondisi alam misalkan dalam pembuatan drainase maka kami akan menyesuaikan dengan air pasang surut, tidak mungkin kami akan bekerja diwaktu air pasang. Jadi waktu agak sedikit molor dan kedua faktor cuaca. Kendala lainnya juga adalah akses internet. Kendala-kendala inilah yang membuat laporan kami menjadi tidak tepat waktu atau sedikit terhambat. (Tahap Pelaporan belum sesuai dengan Permendagri No. 113 Tahun 2014). 
e. Tahap Pertanggungjawaban. Tentunya setelah kami melaksanakan realisasi pelaksanaan APBDes maka kami membuat laporan pertanggungjawaban. (Tahap Pertanggungjawaban sudah sesuai dengan Permendagri No. 113 Tahun 2014).

\section{Pembahasan}

Kecamatan Tatapaan adalah salah satu dari 17 Kecamatan yang ada di Kabupaten Minahasa Selatan yang mendapatkan dana bantuan berupa Dana Desa (DD) atau dana yang bersumber dari Anggaran Pendapatan
Belanja Negara (APBN) maka dari itu Kecamatan Tatapaan memiliki kewajiban untuk mengelola Dana Desa (DD) sesuai dengan peraturan yang berlaku dalam Peraturan Menteri Dalam Negeri (Permendagri) No 113 Tahun 2014. Pemanfaatan dana desa di Kecamatan Tatapaan digunakan untuk Pengerasan jalan, pembuatan jalan paving, pembentukan bumdes, pembuatan embung desa, peningkatan pendidiakan lewat didirikannya PAUD, peningkatan pelayanan kesehatan lewat posyandu dan masih banyak lagi.

Tabel 1. Laporan Realisasi Pelaksanaan APBDes DESA SULU

\begin{tabular}{|c|c|c|c|c|}
\hline Kode Rek & Uraian & $\begin{array}{l}\text { Anggaran } \\
\text { (Rp) }\end{array}$ & $\begin{array}{l}\text { Realisasi } \\
\text { (Rp) }\end{array}$ & $\begin{array}{c}\text { Lebih/Kurang } \\
\text { (Rp) }\end{array}$ \\
\hline 1. & PENDAPATAN & & & \\
\hline 1.1. & Pendapatan Asli Desa & 650.000 & 104.224 & 545.776 \\
\hline 1.1.4 & Lain-lain Pendapatan Asli Desa & 650.000 & 104.224 & 545.776 \\
\hline 1.2 & Pendapatan Transfer & 1.028.891.000 & 586.034 .600 & 442.856 .400 \\
\hline 1.2 .1 & Dana Desa & 715.891 .000 & 429.534 .600 & 286.536 .400 \\
\hline \multirow[t]{2}{*}{1.2 .3} & Alokasi Dana Desa & 313.000 .000 & 156.500 .000 & 156.500 .000 \\
\hline & JUMLAH PENDAPATAN & 1.029.541.000 & 586.138 .824 & 443.402 .176 \\
\hline 2.1 & Bidang Penyelenggaraan Pemerintahan Desa & 306.326 .564 & 143.940 .000 & 162.386 .564 \\
\hline 2.2 & Bidang Pelaksanaan Pembangunan Desa & 675.391 .000 & 428.848 .300 & 246.542 .700 \\
\hline \multirow[t]{3}{*}{2.4} & Bidang Pemberdayaan Masyarakat & 73.000 .000 & 0 & 73.000 .000 \\
\hline & JUMLAH BELANJA & 1.054.717.564 & 572.788 .300 & 481.929 .264 \\
\hline & SURPLUS / DEFISIT & $(25.176 .564)$ & 13.350.524 & (38.527. 088) \\
\hline 3.1 & Penerimaan Pembiayaan & 25.176 .564 & 0 & 25.176 .564 \\
\hline \multirow[t]{3}{*}{3.1 .1} & Sisa Lebih Perhitungan Anggaran Tahun Sebelumnya & 25.176 .564 & 0 & 25.176 .564 \\
\hline & JUMLAH PEMBIAYAAN & 25.176.564 & 0 & 25.176.564 \\
\hline & SISA LEBIH/KURANG PERHITUNGAN ANGGARAN & 0 & 13.350.524 & $(13.350 .524)$ \\
\hline
\end{tabular}

Sumber: Rencana Pembangunan jangka Menengah Desa Sulu, 2018

a. Tahap Perencanaan pengelolaan Dana Desa yang ada di Desa Sulu dimana penyusunan Anggaran Pendapatan dan Belanja Desa (APBDes) Sekertaris Desa menyusun berdasarkan RKPDesa untuk tahun 2018, Desa Sulu memiliki Pendapatan sebesar Rp 1.029.541.000 yang terdiri dari Pendapatan Asli Desa, Pendapatan Transfer (Dana Desa dan Alokasi Dana Desa). Setelah penyusunan Anggaran Pendapatan dan Belanja Desa (APBDesa) telah selesai maka Sekertaris Desa memberikan kepada Kepala Desa dari Kepala Desa bersama BPD membahas lebih lanjut dan disepakati bersama paling lambat bulan Oktober tahun berjalan.

b. Tahap Pelaksanaan menjadi bagian terpenting dalam suatu kegiatan atau pelaksanaan program, di Desa Sulu dalam pengelolaan Dana Desa. Dalam pengelolaan dana desa di Desa Sulu menerima Dana Desa sebesar Rp
715.891.000 dimana dalam realisasi penyaluran ke Rekening Kas Desa terbagi atas 3 tahap yaitu Tahap pertama sebesar 20\%, Tahap Kedua 40\% dan Tahap Ketiga 40\%. Dana Desa proritasnya untuk Bidang Pelaksanaan Pembangunan Desa dengan jumlah Anggaran Rp 675.391.000 diantaranya untuk pendanaan pelaksanaan Kegiatan Pembangunan dan Pengembangan Paving Blok, Kegiatan Pembangunan dan Pengembangan Gorong-Gorong, Kegiatan Pengadaan Batas Desa dan Papan Nama Jalan dan Kegiatan Pengadaan dan Pengembangan Kegiatan Posyandu dan Bidang Pemberdayaan Masyarakat dengan jumlah Anggaran 73.000.000 diantaranya untuk pendanaan pelaksanaan kegiatan Penyusunan Profil Desa, Kegiatan Pendidikan dan Pelatihan Bagi Hukum Tua, Perangkat Desa dan Kegiatan Peningkatan Kapasitas Pemerintah Desa. 
c. Tahap Penatausahaan pengelolaan Dana Desa di Desa Sulu yang memiliki tanggungjawab disini ialah Bendahara Desa dimana setiap penerimaan dan pengeluaran dana desa untuk pembiayaan-pembiayaan yang ada bendahara desa harus mencatat setiap pengeluaran dan penerimaan dana tersebut dan diwajibkan mempertanggungjawabkan setiap dana yang diterima dan dikeluarkan untuk desa agar tidak terdapat kecurangan. Penatausahaan yang dilakukan oleh Bendahara Desa yang ada di Desa Sulu melalui pencatatan terdiri dari Buku Kas Umum, Buku Kas Pembantu Pajak dan Buku Bank guna membantu pencatatannya dan semuanya itu dilaporkan kepada Kepala Desa paling lambat disampaikan pada tanggal 10 bulan berikutnya.

d. Pada tahap Pelaporan dan Pertanggungjawaban tentang pengelolaan dana desa yang ada di Desa Sulu, pemerintah desa (Kepala Desa) menyampaikan laporan realisasi pelaksanaan APBDesa kepada Bupati/Walikota untuk laporan semester pertama dan laporan semester akhir tahun meskipun dalam menyampaikan laporan pertanggungjawaban realisasi pelaksanaan APBDesa mengalami keterlambatan dikarenakan faktor SDM yang sudah 3 kali mengalami pergantian tetapi format pembuatan laporan sesuai dengan peraturan yang ada namun pemerintah Desa Sulu tetap mempertanggungjawabkan laporan realisasi pelaksanaan.

Tabel 2. Laporan Realisasi Pelaksanaan APBDes DESA PASLATEN

\begin{tabular}{|c|c|c|c|c|}
\hline Kode Rek & Uraian & $\begin{array}{c}\text { Anggaran } \\
\text { (Rp) }\end{array}$ & $\begin{array}{c}\text { Realisasi } \\
(\mathrm{Rp})\end{array}$ & $\begin{array}{c}\text { Lebih/Kurang } \\
\text { (Rp) }\end{array}$ \\
\hline 1. & PENDAPATAN & & & \\
\hline 1.1. & Pendapatan Asli Desa & 600.000 & 220.684 & 379.316 \\
\hline 1.1 .4 & Lain-lain Pendapatan Asli Desa & 600.000 & 220.684 & 379.316 \\
\hline 1.2 & Pendapatan Transfer & 1.022.233.000 & 220.022 .600 & 802.210 .400 \\
\hline 1.2.1 & Dana Desa & 710.713 .000 & 142.142 .600 & 568.570 .400 \\
\hline \multirow[t]{2}{*}{1.2 .3} & Alokasi Dana Desa & 311.520 .000 & 77.880 .000 & 233.640 .000 \\
\hline & JUMLAH PENDAPATAN & 1.022.833.000 & 220.243 .284 & 802.589 .716 \\
\hline 2.1 & Bidang Penyelenggaraan Pemerintahan Desa & 314.715 .000 & 77.897 .500 & 236.817 .500 \\
\hline 2.2 & Bidang Pelaksanaan Pembangunan Desa & 488.452 .000 & 138.997 .000 & 349.454 .200 \\
\hline \multirow[t]{3}{*}{2.4} & Bidang Pemberdayaan Masyarakat & 167.261 .000 & 2.700 .000 & 164.561 .000 \\
\hline & JUMLAH BELANJA & 970.428 .000 & 219.595.300 & 750.832 .700 \\
\hline & SURPLUS / DEFISIT & 52.405 .000 & 647.984 & 51.757 .016 \\
\hline 3.1 & Penerimaan Pembiayaan & 11.595 .000 & 0 & 11.595 .000 \\
\hline \multirow[t]{3}{*}{3.1 .1} & Sisa Lebih Perhitungan Anggaran Tahun Sebelumnya & 11.595 .000 & 0 & 11.595 .000 \\
\hline & JUMLAH PEMBIAYAAN & $(52.405 .000)$ & 0 & $(52.405 .000)$ \\
\hline & SISA LEBIH/KURANG PERHITUNGAN ANGGARAN & $\mathbf{0}$ & 647.984 & (647.984) \\
\hline
\end{tabular}

a. Tahap Perencanaan pengelolaan Dana Desa yang ada di Desa Paslaten dimana penyusunan Anggaran Pendapatan dan Belanja Desa (APBDes) Sekertaris Desa menyusun berdasarkan RKPDesa untuk tahun 2018, Desa Paslaten memiliki Pendapatan sebesar Rp 1.022.833.000 yang terdiri dari Pendapatan Asli Desa, Pendapatan Transfer (Dana Desa dan Alokasi Dana Desa). Setelah penyusunan Anggaran Pendapatan dan Belanja Desa (APBDesa) telah selesai maka Sekertaris Desa memberikan kepada Kepala Desa dari Kepala Desa bersama BPD membahas lebih lanjut dan disepakati bersama paling lambat bulan Oktober tahun berjalan.

b. Tahap Pelaksanaan menjadi bagian terpenting dalam suatu kegiatan atau pelaksanaan program, di Desa Paslaten dalam pengelolaan Dana Desa. Dalam pengelolaan dana desa di Desa Paslaten menerima Dana Desa sebesar Rp 710.713 .000 dimana dalam realisasi penyaluran ke Rekening Kas Desa terbagi atas 3 tahap yaitu Tahap pertama sebesar 20\%, Tahap Kedua 40\% dan Tahap Ketiga 40\%. Dana Desa proritasnya untuk Bidang Pelaksanaan Pembangunan Desa dengan jumlah Anggaran Rp 488.452.000 diantaranya 
untuk pendanaan pelaksanaan kegiatan Pembangunan dan Pengembangan Sarana Drainase, Kegiatan Pembangunan Bangunan PAUD dan Bidang Pemberdayaan Masyarakat dengan jumlah Anggaran 167.261.000 diantaranya untuk pendanaan pelaksanaan kegiatan Pelayanan Bantuan Insentif Guru PAUD, Kegiatan Penyusunan Profil Desa, Kegiatan Pelatihan Manajemen Pemerintah Desa, Kegiatan Pelatihan Kelembagaan Desa, Kegiatan Peningkatan Kelompok Perempuan, Kegiatan Peningkatan Kapasitas Kelompok Masyarakat, Kegiatan Pelatihan Pengurus Badan Usaha Milik Desa (BUMDes), Kegiatan Pelatihan Kader Kesehatan Masyarakat, Kegiatan Pengembangan dan Pemanfaatan POSYANDU.

c. Tahap Penatausahaan pengelolaan Dana Desa di Desa Paslaten yang memiliki tanggungjawab disini ialah Bendahara Desa dimana setiap penerimaan dan pengeluaran dana desa untuk pembiayaan-pembiayaan yang ada bendahara desa harus mencatat setiap pengeluaran dan penerimaan dana tersebut dan diwajibkan mempertanggungjawabkan setiap dana yang diterima dan dikeluarkan untuk desa agar tidak terdapat kecurangan. Penatausahaan yang dilakukan oleh Bendahara Desa yang ada di Desa Paslaten melalui pencatatan terdiri dari Buku Kas Umum, Buku Kas Pembantu Pajak dan Buku Bank guna membantu pencatatannya dan semuanya itu dilaporkan kepada Kepala Desa paling lambat disampaikan pada tanggal 10 bulan berikutnya.

d. Pada tahap Pelaporan pertanggungjawaban tentang pengelolaan dana desa yang ada di Desa Paslaten, pemerintah desa (Kepala Desa) menyampaikan laporan realisasi pelaksanaan APBDesa kepada Bupati/Walikota untuk laporan semester pertama dan laporan semester akhir tahun meskipun dalam menyampaikan laporan pertanggungjawaban realisasi pelaksanaan APBDesa mengalami keterlambatan dikarenakan hibah lahan dari keluarga sehingga terjadi keterlambatan dalam pekerjaan dan pembuatan laporan.

Tabel 3. Laporan Realisasi Pelaksanaan APBDes DESA PUNGKOL

\begin{tabular}{|c|c|c|c|c|}
\hline Kode Rek & Uraian & $\begin{array}{c}\text { Anggaran } \\
\text { (Rp) }\end{array}$ & $\begin{array}{l}\text { Realisasi } \\
\text { (Rp) }\end{array}$ & $\begin{array}{c}\text { Lebih/Kurang } \\
\text { (Rp) }\end{array}$ \\
\hline 1. & PENDAPATAN & & & \\
\hline 1.1. & Pendapatan Asli Desa & 11.200 .000 & 11.271.054 & 71.054 \\
\hline 1.1 .1 & Hasil Usaha Desa & 3.436 .000 & 3.436 .000 & 0 \\
\hline 1.1 .4 & Lain-lain Pendapatan Asli Desa & 700.000 & 771.054 & 71.054 \\
\hline 1.2 & Pendapatan Transfer & 948.350 .000 & 948.350 .000 & $\mathbf{0}$ \\
\hline 1.2 .1 & Dana Desa & 681.250 .000 & 681.250 .000 & 0 \\
\hline \multirow[t]{2}{*}{1.2 .3} & Alokasi Dana Desa & 267.100 .000 & 267.100 .000 & 0 \\
\hline & JUMLAH PENDAPATAN & 959.550 .000 & 959.621 .054 & \\
\hline 2.1 & Bidang Penyelenggaraan Pemerintahan Desa & 298.531 .049 & 282.453 .883 & 16.077.166 \\
\hline 2.2 & Bidang Pelaksanaan Pembangunan Desa & 518.162 .900 & 518.162 .900 & 0 \\
\hline 2.3 & Bidang Pembinaan Kemasyarakatan & 7.200 .000 & 7.200 .000 & 0 \\
\hline \multirow[t]{3}{*}{2.4} & Bidang Pemberdayaan Masyarakat & 129.395 .200 & 117.975 .200 & 11.420 .000 \\
\hline & JUMLAH BELANJA & 953.289.149 & 925.791 .983 & 27.497.166 \\
\hline & SURPLUS / DEFISIT & 6.260 .851 & 33.829 .071 & $(27.568 .220)$ \\
\hline 3.1 & Penerimaan Pembiayaan & 48.739 .149 & 48.739 .149 & 0 \\
\hline 3.1 .1 & Sisa Lebih Perhitungan Anggaran Tahun Sebelumnya & 48.739 .149 & 48.739 .149 & 0 \\
\hline 3.2 & Pengeluaran Pembiayaan & 55.000 .000 & 55.000 .000 & 0 \\
\hline \multirow[t]{3}{*}{3.2 .2} & Penyertaan Modal Desa & 55.000 .000 & 55.000 .000 & 0 \\
\hline & JUMLAH PEMBIAYAAN & $(6.260 .851)$ & $(6.260 .851)$ & $\mathbf{0}$ \\
\hline & SISA LEBIH/KURANG PERHITUNGAN ANGGARAN & 0 & 27.568.220 & (27.568.220) \\
\hline
\end{tabular}

Sumber: Rencana Pembangunan jangka Menengah Desa Pungkol, 2018 
a. Tahap Perencanaan pengelolaan Dana Desa yang ada di Desa Pungkol dimana penyusunan Anggaran Pendapatan dan Belanja Desa (APBDes) Sekertaris Desa menyusun berdasarkan RKPDesa untuk tahun 2018, Desa Paslaten memiliki Pendapatan sebesar Rp 959.550 .000 yang terdiri dari Pendapatan Asli Desa, Hasil Usaha Desa, Lain-lain pendapatan asli desa, Pendapatan Transfer (Dana Desa dan Alokasi Dana Desa). Setelah penyusunan Anggaran Pendapatan dan Belanja Desa (APBDesa) telah selesai maka Sekertaris Desa memberikan kepada Kepala Desa dari Kepala Desa bersama BPD membahas lebih lanjut dan disepakati bersama paling lambat bulan Oktober tahun berjalan.

b. Tahap Pelaksanaan menjadi bagian terpenting dalam suatu kegiatan atau pelaksanaan program, di Desa Pungkol dalam pengelolaan Dana Desa. Dalam pengelolaan dana desa di Desa Pungkol menerima Dana Desa sebesar $\mathrm{Rp}$ 681.250.000 dimana dalam realisasi penyaluran ke Rekening Kas Desa terbagi atas 3 tahap yaitu Tahap pertama sebesar 20\%, Tahap Kedua 40\% dan Tahap Ketiga 40\%. Dana Desa proritasnya untuk Bidang Pelaksanaan Pembangunan Desa dengan jumlah Anggaran Rp 518.162.900 diantaranya untuk pendanaan pelaksanaan kegiatan Pembangunan dan Pengembangan Paving Blok, Kegiatan Pembangunan dan Pengembangan Perkerasan, Kegiatan Pengadaan Jaringan Distribusi Tenaga Listrik dan Bidang Pemberdayaan Masyarakat dengan jumlah Anggaran Rp 129.395.200 diantaranya untuk pendanaan pelaksanaan kegiatan Penyusunan Perencanaan dan Penganggaran,
Kegiatan Pendidikan dan Pelatihan Bagi Hukum dan Perangkat Desa, Kegiatan Pelatihan Manajemen Pemerintahan Desa, Kegiatan Pelatihan Pengurus Badan Usaha Milik Desa, Kegiatan Pelayanan Bantuan Insentif Kader Kesehatan.

c. Tahap Penatausahaan pengelolaan Dana Desa di Desa Pungkol yang memiliki tanggungjawab disini ialah Bendahara Desa dimana setiap penerimaan dan pengeluaran dana desa untuk pembiayaan-pembiayaan yang ada bendahara desa harus mencatat setiap pengeluaran dan penerimaan dana tersebut dan diwajibkan mempertanggungjawabkan setiap dana yang diterima dan dikeluarkan untuk desa agar tidak terdapat kecurangan. Penatausahaan yang dilakukan oleh Bendahara Desa yang ada di Desa Pungkol melalui pencatatan terdiri dari Buku Kas Umum, Buku Kas Pembantu Pajak dan Buku Bank guna membantu pencatatannya dan semuanya itu dilaporkan kepada Kepala Desa paling lambat disampaikan pada tanggal 10 bulan berikutnya.

d. Pada tahap Pelaporan pertanggungjawaban tentang pengelolaan dana desa yang ada di Desa Pungkol, pemerintah desa (Kepala Desa) menyampaikan laporan realisasi pelaksanaan APBDesa kepada Bupati/Walikota untuk laporan semester pertama dan laporan semester akhir tahun meskipun dalam menyampaikan laporan pertanggungjawaban realisasi pelaksanaan APBDesa mengalami keterlambatan tetapi format pembuatan laporan sesuai dengan peraturan yang ada. 
Tabel 4. Laporan Realisasi Pelaksanaan APBDes DESA RAP-RAP

\begin{tabular}{llrrr}
\hline KODE REK & URAIAN & $\begin{array}{l}\text { ANGGARAN } \\
(\mathbf{R p})\end{array}$ & $\begin{array}{l}\text { REALISASI } \\
(\mathbf{R p})\end{array}$ & $\begin{array}{l}\text { LEBIH/KURANG } \\
(\mathbf{R p})\end{array}$ \\
\hline 1. & PENDAPATAN & $\mathbf{7 2 7 . 7 9 6 . 0 0 0}$ & $\mathbf{4 3 6 . 6 7 7 . 6 0 0}$ & $\mathbf{2 9 1 . 1 1 8 . 4 0 0}$ \\
1.2 & Pendapatan Transfer & 727.796 .000 & 436.677 .600 & 291.118 .400 \\
1.2 .1 & Dana Desa & $\mathbf{7 2 7 . 7 9 6 . 0 0 0}$ & $\mathbf{4 3 6 . 6 7 7 . 6 0 0}$ & $\mathbf{2 9 1 . 1 1 8 . 4 0 0}$ \\
& JUMLAH PENDAPATAN & 585.476 .000 & 436.166 .800 & 149.309 .200 \\
2.2 & Bidang Pelaksanaan Pembangunan Desa & 117.938 .000 & 0 & 117.938 .000 \\
2.4 & Bidang Pemberdayaan Masyarakat & $\mathbf{7 0 3 . 4 1 4 . 0 0 0}$ & $\mathbf{4 3 6 . 1 6 6 . 8 0 0}$ & $\mathbf{2 6 7 . 2 4 7 . 2 0 0}$ \\
& JUMLAH BELANJA & 24.382 .000 & 510.800 & 23.871 .200 \\
& SURPLS / DEFISIT & 618.000 & 0 & 618.000 \\
3.1 & Penerimaan Pembiayaan & 618.000 & 0 & 618.000 \\
3.1 .1 & Sisa Lebih Perhitungan Anggaran Tahun Sebelumnya & 25.000 .000 & 0 & 25.000 .000 \\
3.2 & Pengeluaran Pembiayaan & 25.000 .000 & 0 & 25.000 .000 \\
3.2 .2 & Penyertaan Modal Desa & $\mathbf{( 2 4 . 3 8 2 . 0 0 0 )}$ & $\mathbf{0}$ & $\mathbf{( 2 4 . 3 8 2 . 0 0 0 )}$ \\
& JUMLAH PEMBIAYAAN & $\mathbf{0}$ & $\mathbf{5 1 0 . 8 0 0}$ & $\mathbf{( 5 1 0 . 8 0 0 )}$ \\
\hline
\end{tabular}

a. Tahap Perencanaan pengelolaan Dana Desa yang ada di Desa Rap-Rap dimana penyusunan Anggaran Pendapatan dan Belanja Desa (APBDes) Sekertaris Desa menyusun berdasarkan RKPDesa untuk tahun 2018, Desa Rap-Rap memiliki Pendapatan sebesar Rp 727.796.000 yang berasal dari Dana Desa. Setelah penyusunan Anggaran Pendapatan dan Belanja Desa (APBDesa) telah selesai maka Sekertaris Desa memberikan kepada Kepala Desa dari Kepala Desa bersama BPD membahas lebih lanjut dan disepakati bersama paling lambat bulan Oktober tahun berjalan.

b. Tahap Pelaksanaan menjadi bagian terpenting dalam suatu kegiatan atau pelaksanaan program, di Desa Pungkol dalam pengelolaan Dana Desa. Dalam pengelolaan dana desa di Desa Pungkol menerima Dana Desa sebesar Rp 727.796.000 dimana dalam realisasi penyaluran ke Rekening Kas Desa terbagi atas 3 tahap yaitu Tahap pertama sebesar 20\%, Tahap Kedua 40\% dan Tahap Ketiga 40\%. Dana Desa proritasnya untuk Bidang Pelaksanaan Pembangunan Desa dengan jumlah Anggaran Rp 585.476.000 diantaranya untuk pendanaan pelaksanaan kegiatan Pembangunan dan Pengembangan Paving Blok dan Kegiatan Pembangunan dan Pengembangan Talud dan Bidang Pemberdayaan Masyarakat dengan jumlah Anggaran Rp 117.938.000 diantaranya untuk pendanaan pelaksanaan kegiatan
Peningkatan Kapasitas Kelompok Pemuda, Kegiatan Pengembangan Kapasitas Paralegal Desa, Kegiatan Pelatihan Pengurus Badan Usaha Milik Desa (BUMDes), Kegiatan Pengelolaan Peningkatan Gizi Bagi Balita dan Anak dan Kegiatan Peningkatan Kapasitas Pemerintah Desa.

c. Tahap Penatausahaan pengelolaan Dana Desa di Desa Pungkol yang memiliki tanggungjawab disini ialah Bendahara Desa dimana setiap penerimaan dan pengeluaran dana desa untuk pembiayaan-pembiayaan yang ada bendahara desa harus mencatat setiap pengeluaran dan penerimaan dana tersebut dan diwajibkan mempertanggungjawabkan setiap dana yang diterima dan dikeluarkan untuk desa agar tidak terdapat kecurangan. Penatausahaan yang dilakukan oleh Bendahara Desa yang ada di Desa Pungkol melalui pencatatan terdiri dari Buku Kas Umum, Buku Kas Pembantu Pajak dan Buku Bank guna membantu pencatatannya dan semuanya itu dilaporkan kepada Kepala Desa paling lambat disampaikan pada tanggal 10 bulan berikutnya.

d. Pada tahap Pelaporan Pertanggungjawaban tentang pengelolaan dana desa yang ada di Desa Rap-Rap dimana pemerintah desa (Kepala Desa) menyampaikan laporan realisasi pelaksanaan APBDesa kepada Bupati/Walikota untuk laporan semester pertama dan laporan semester akhir 
tahun meskipun dalam menyampaikan laporan pertanggungjawaban realisasi pelaksanaan APBDesa mengalami keterlambatan karena beberapa faktor yang telah dijelaskan sebelumnya tetapi format pembuatan laporan sesuai dengan peraturan yang ada.

\section{Kesimpulan dan saran}

Kesimpulan

Kesimpulan atas hasil penelitian yang telah dilakukan adalah:

1. Mengenai pengelolaan dana desa berdasarkan permendagri No.113 Tahun 2014 di Kecamatan Tatapaan khususnya di 4 (empat) desa yaitu: Desa Sulu, Desa Paslaten, Desa Pungkol, dan Desa RapRap yang tahapannya mulai dari proses Perencanaan, Pelaksanaan, Penatausahaan, Pelaporan dan Pertanggungjawaban yang dilakukan oleh Pemerintah yang ada di Kecamatan Tatapaan dapat disimpulkan bahwa dalam proses Perencanaan, Pelaksanaan, Penatausahaan dan Pertanggungjawaban sudah sesuai dengan Permendagri No. 113 Tahun 2014, namun dalam proses pelaporan di Kecamatan Tatapaan dari hasil penelitian menunjukan bahwa untuk laporan pertanggungjawaban di Kecamatan Tatapaan di Tahun 2017 dan 2018 mengalami beberapa kendala diantaranya di Tahun 2017 dalam pembuatan laporan masih manual jadi SDM yang kurang handal masih kesulitan dalam pembuatan laporan sehingga dalam proses pencairan dana sering terjadi keterlambatan, namun ditahun 2018 sudah dimudahkan dalam pembuatan laporan karena sudah menggunakan aplikasi SISKEUDES. Ada juga kendala lainnya dimana dalam pembangunan proyek untuk pembuatan jalan misalnya kadang menjadi kendala karena hibah tanah dari keluarga pemilik lahan dan juga pekerjaan yang berbenturan dengan kondisi alam,misalkan dalam pembuatan drainase maka kami akan menyesuaikan dengan air pasang surut tidak mungkin kami akan bekerja diwaktu air pasang, jadi waktu agak sedikit molor dan juga kendala lainnya adalah akses internet pada waktu itu.

2. Dengan adanya Dana Desa bagi masyarakat yang ada di Kecamatan Tatapaan khususnya di di 4 (empat) desa yaitu: Desa Sulu, Desa Paslaten, Desa Pungkol, dan Desa Rap-Rap membawah dampak positif dalam kehidupan masyarakat karena dengan adanya Dana Desa tampak terlihat jelas kemajuan desa baik dalam bentuk fisik maupun nonfisik diantaranya Pengerasan jalan perkebunan, pembuatan embung desa, pembuatan jalan paving, pembentukan BUMDES, pendirian sekolah PAUD, peningkatan pelayanan posyandu, pelatihan kewirausahaan, pembuatan drainase, dan lain-lain.

\section{Saran}

1. Seperti yang telah dikemukan sebelumnya bahwa dalam proses pelaporan terjadi hambatan karena SDM yang kurang handal, jadi disini sebaiknya pemerintah desa dalam hal ini Kepala Desa harus memilih Sekertaris Desa dan Bendahara Desa yang handal dan memiliki kompeten dalam bidangnya dan baiknya juga SDM tersebut sangat penting untuk mengikuti pelaihan tentang pengelolaan keuangan desa sehingga dapat mengatasi masalah dalam pelaporan dan pertanggungjawaban dana desa.

2. Terjadinya hambatan dalam pembuatan proyek dikarenakan hibah lahan oleh keluarga, jadi sebelum ditetapkannya proyek tersebut ada baiknya pemerintah desa terlebih dahulu merundingkan dengan keluarga pemilik lahan.

3. Untuk Pemerintah yang ada di Kecamatan Tatapaan khususnya yang ada di di 4 (empat) desa yaitu: Desa Sulu, Desa Paslaten, Desa Pungkol, dan Desa Rap-Rap diharapkan dapat melakukan laporan pertanggungjawaban pelaksanaan APBDesa dimasing-masing desa tepat waktu sesuai yang ditentukan dalam peraturan yang dibuat oleh 
pemerintah dan disertai dengan asas-asas pengelolaan keuangan desa.

4. Penelitian selanjutnya diharapkan agar dapat membahas komponen Pengelolaan Dana Desa secara detail dan terperinci termasuk untuk penganggaran dan pengawasan, nilai kinerja pemerintah desa dan sebagainya.

\section{Daftar pustaka}

Bastian, I. (2012). Akuntansi sektor publik. Jakarta: Erlangga

Bawon, R., Karamoy, H., \& Warongan, J.D.L. (2018). Analisis prosedur pelaksanaan pengelolaan dana desa pada Desa Passi 2 Kecamatan Passi Barat. Going Concern: Jurnal Riset Akuntansi, 13 (4), $1-4$. https://doi.org/10.32400/gc.13.04.20990.2018.

Dedi, N. (2012). Akuntansi sektor publik. Yogyakarta: Pustaka Baru Press.

Halim, A. (2012). Akuntansi sektor publik: Akuntansi keuangan daerah. Edisi 4. Jakarta: Salemba Empat.

Halim, A. (2014). Akuntansi sektor publik: Akuntansi keuangan daerah, Edisi 4. Jakarta: Salemba Empat.

Mahmudi. (2015). Manajemen kinerja sektor publik. Edisi 3. Yogyakarta: UPP STIM YKPN.

Peraturan Menteri Dalam Negeri Nomor 113 Tahun 2014.

Rondonuwu, R. H., Tinangon, J. J., \& Budiarso, N. (2015). Analisis efisiensi dan efektivitas pengelolaan keuangan daerah pada Dinas Pendapatan Daerah Kabupaten Minahasa. Jurnal EMBA, 3(4), 23-32. https://doi.org/10.35794/emba.v3i4.10580.

Shuha, K., Syofyan, E., \& Halmawati. (2018). Analisis pengelolaan dana desa (Studi kasus pada DesaDesa Selingkungan Kecamatan Lubuk Alung Kabupaten Padang Pariaman. Jurnal Akuntansi, 6(2), $1-21$. http://ejournal.unp.ac.id/students/index.php/a $\mathrm{kt} /$ article/view/3787.

Thomas, S. (2013). Akuntansi intermediate, Jilid 1. Yogyakarta: Graha Ilmu.

Undang-Undang Republik Indonesia Nomor 6 Tahun 2014 tentang Desa.

Sujarweni,V. W. (2015). Akuntansi desa. Yogyakarta: Penerbit Pustaka Baru Press.

Sujarweni, V. W. (2015). Akuntansi sektor publik. Yogyakarta: Penerbit Pustaka Baru Press.

Suwardjono. (2017). Teori Akuntansi. Yogyakarta: BPFE

Warren, C., Reeve, M. J., \& Fess, P. E. (2015). Pengantar akuntansi. Jakarta: Salemba Empat. 